\title{
Basic Laws of Anti-Corruption in the Five ASEAN Countries: Models and Options
}

\author{
Lijun Kong, Jingjing Wei, Xi Yang, Ying Guo, Sheng Su \\ Law School, Guangxi University, Nanning, China \\ Email: lawklj@foxmail.com
}

How to cite this paper: Kong, L. J., Wei, J. J., Yang, X., Guo, Y., \& Su, S. (2021). Basic Laws of Anti-Corruption in the Five ASEAN Countries: Models and Options. Advances in Applied Sociology, 11, 735-746.

https://doi.org/10.4236/aasoci.2021.1112060

Received: December 4, 2021

Accepted: December 27, 2021

Published: December 30, 2021

Copyright $\odot 2021$ by author(s) and Scientific Research Publishing Inc. This work is licensed under the Creative Commons Attribution-NonCommercial International License (CC BY-NC 4.0). http://creativecommons.org/licenses/by-nc/4.0/ (c) (i) \&) Open Access

\begin{abstract}
Corruption is a cancer in the world that destroys the credibility of the state and damages the interests of the people. It is the consensus and choice of the international community to prevent and punish corruption through anti-corruption legislation. There are three legislative models of anti-corruption basic laws in the world: the criminal legislative model which focuses on ex post punishment; the preventive legislative model which focuses on advancing prevention; the comprehensive legislative model which combines criminal punishment and pre-prevention. The Supervision Law is the latest achievement of China's specialized anti-corruption legislation, but from the viewpoint of its legislative purpose and the setting of its provisions, it is not yet able to shoulder the responsibility of being conceptual design of a basic anti-corruption law. In the long run, China's anti-corruption work needs a basic anti-corruption law construct with both prevention and punishment of corruption under comprehensive legislative model to lead and guide China's anti-corruption cause from both "prevention" and "punishment" aspects, and accelerate the modernization of China's corruption governance system and governance capacity.
\end{abstract}

\section{Keywords}

Five ASEAN Countries, Anti-Corruption, Basic Law, Legislative Model

\section{Introduction}

Severe corruption issues will not only lead to a large loss of state-owned assets, but also detrimental to the improvement of national governance capabilities and governance levels. Countries suffering from corruption began to adopt Anti-corruption legislation to prevent and combat corruption, and gradually developed from fragmented Anti-corruption norms to use a basic Anti-corruption 
law for top-level design and dominate the national Anti-corruption legal system. Malaysia, Myanmar, the five ASEAN countries of Vietnam, the Philippines and Laos are no exception. Due to differences in political systems and legislative traditions, the five countries have different tendencies in the formulation of the basic Anti-corruption laws, forming different legislative models. This article intends to study and analyze the legislative models of the basic Anti-corruption laws behind the five countries, so as to provide a reference for the choice of the model for the formulation of China's basic Anti-corruption laws.

\section{Model of Criminal Legislative Model Focusing on Post-Incident Punishment}

The criminal legislation model emphasizes the criminal punishment function of Anti-corruption legislation and focuses on direct attacks on corruption (Michael, 2019). This model can be further divided into two sub-models: one is a "Three-in-one" model that integrates criminal substantive law, procedural law, and organizational law; the other is a "Three-in-one" model that integrates criminal substantive law and procedural law, "Two-body in one" mode (Liu, 2017). The criminal legislative model is biased towards a single criminal punishment, and is based on the actual result of corruption, so it has a certain passivity (Peng, 2021). Among the five ASEAN countries that this topic focuses on, the basic Anti-corruption laws of Malaysia and Myanmar have adopted this model.

\subsection{Malaysian Anti-Corruption Commission Act}

Since the Federation of Malaya in the last century, Malaysia has been well aware of the dangers of corruption and regards integrity as the top priority of the national plan. ASEAN is second only to Singapore and Brunei (Nawab et al., 2006). The history of the Malaysian government's use of legal measures to combat corruption began with the "Corruption Prevention Act" promulgated in 1950 (Mansoor Marican, 1979). After more than half a century of legislative practice and exploration, "Malaysian Anti-corruption Commission Act" 2009 (Act 694) have been improved day by day, representing the highest level of current Malaysian Anti-corruption legislation (Gong \& Yang, 2019). As the basic law of Malaysia's Anti-corruption, the Anti-corruption Commission Act integrates criminal substantive law, procedural law and organizational law. It not only stipulates the composition, responsibilities, and powers of the Anti-corruption committee, but also stipulates Corruption crimes and penalties, investigations, searches, seizures, arrests, evidence, prosecutions, and trials and other criminal entities and procedural norms belong to a very typical criminal legislation model.

Under the criminal legislative model, the Anti-corruption Commission Law has a wide range of penalties for corruption and bribery and severe methods. For example, Article 19 stipulates that "Even though the purpose of bribery is not realized or the entrusted matter has nothing to do with the client's job or business, the bribery still constitutes a crime", and pay attention to the combination 
of personal punishment and fines. If Article 24 violates the provisions of the law, you may face imprisonment of not more than 20 years and high fines. The law not only stipulates the seven basic corruption crimes, bribery crimes, agency bribery or bribery crimes, agents deliberately defrauding clients, corruption resulting in the withdrawal of bids, bribery crimes of public agency officials, bribery crimes of foreign public officials, and the crime of bribery by officials using influence. Crimes and penalties, on the basis of which general crimes and general penalties are stipulated as culpable clauses, that is, "Any court, prosecutor, or committee official or representative who fails to comply with the provisions of this law or performs relevant duties in accordance with the provisions of this law Any order, instruction or notice issued by the person of the organization shall be a crime". And "Any offender convicted of a crime under this law, if this law does not specify the specific punishment for the crime, may be fined less than 10,000 ringgit, or imprisoned for less than two years, or both." The crime and the pervasiveness of the criminal law design. In order to strengthen the punishment of corruption, the Anti-corruption Commission Law has comprehensively upgraded the previous Anti-corruption Bureau, and established an independent and responsible Anti-corruption agency, the Anti-corruption Commission, which is responsible for accepting and reviewing the provisions of this law. Reporting crimes, investigating the reports that the chief committee member or other officials consider feasible, and investigating and investigating suspected of constituting any crimes under this law, attempts to commit crimes suspected of constituting implementation of the provisions of this law, and suspected cases constituting implementation of the provisions of this law Conspiracy of various crimes in order to promote the integrity and responsibility of the public and private sector administration. This law is also compatible with the Criminal Code, the Criminal Procedure Law, the Mutual Assistance in Criminal Matters Act, the Evidence Law, the Election Crime Law, the Police Law, the Customs Law, the Anti-Money Laundering and Counter-Terrorism Financing Law, and the Witness Protection Law. The "Whistleblower Protection Act" and other laws and regulations are matched and coordinated to form the Malaysian Anti-corruption legal system. Generally speaking, since the promulgation of the "Corruption Prevention Act" in the 1950s, Malaysia's Anti-corruption Basic Law has been constantly changing, but it has always focused on criminal punishment and severe crackdowns on corruption crimes, increasing the cost of corruption and forcing officials to maintain integrity. While continuously improving and effectively curbing corruption in the country, the criminal legislation model represented by it also provides a useful reference for other ASEAN countries and plays a good role model.

\subsection{Myanmar Anti-Corruption Law}

In traditional societies, rulers lack in-depth understanding of the root causes of corruption, governance concepts are relatively primitive, and the country lacks 
effective tools for corruption governance. Penalties tend to become the governance methods favored by rulers based on the advantage of short-term results and quick results, leading to corruption governance in traditional society. Rely on heavy punishment doctrine (Wei, 2016). The Myanmar military withdrew from state rule in 2011, and from this year, Myanmar entered the process of social democratization. However, the problems of corruption left over from the military government were more serious. In the early stage of modernization, it was difficult for Myanmar to quickly get rid of its dependence on traditional governance methods. Therefore, the criminal legislation model that focused on direct attacks was given priority by legislators.

Myanmar's current Anti-corruption Law was signed by the former President U Thein Sein on August 7, 2013 in accordance with the Myanmar Constitution, and came into force on September 17 of the same year. Repealed. According to Article 4 of the law, its legislative purposes include "to implement the fight against bribery as a national strategic task" and "effectively punish criminals for bribery" (Hope Sr, 2017). Compared with pre-prevention, Myanmar's Anti-corruption Law emphasizes the legislative concept of post-punishment of bribery and bribery. In particular, the law raises the level of combating bribery and bribery to the level of national strategic tasks, demonstrating the legislator's function of criminal punishment, highly valued. In line with this legislative concept, Chapter 10 "Crimes and Penalties" of the law adopts substantive criminal and criminal penalties for bribery and bribery by the "Competent Authority" under its jurisdiction. For example, if an incumbent administrative officer commits a crime of bribery, he can be sentenced to a fixed-term imprisonment of not more than fifteen years; if a public official commits a crime of bribery, he can be sentenced to a fixed-term imprisonment of not more than ten years. In order to strengthen its crackdown in response to external criticism, an amendment in 2018 adjusted the original scope of application of the law, which was mainly reflected in the revision of the definition of "Corruption": the scope of the anti-corruption law is expanded by extending the subject of "Corruption" from the original "Competent authority" to "Anyone". Compared with the previous main regulation targets public officials or public organizations, the 2018 amendment can theoretically be interpreted as further extending the targets of the law to the private sector and private sectors other than public officials. In addition, the law also sets up procedural provisions for handling corruption cases to ensure the realization of the criminal punishment function. It mainly includes two parts: one is the Anti-corruption commission (the Anti-corruption Commission, ACC), the formation of the pre-trial team and the investigation team; the second is the responsibilities of the aforementioned organizations, which specifically involve the content and procedures of actions taken by each organization when handling cases. For example, the pre-review team and investigation team set up by ACC can conduct investigations after receiving the victim's complaint, including checking and copying the accused's information in banks and other fi- 
nancial institutions, ledgers, purchase or consumption expenditures and other records. And seize the aforementioned materials and illegally acquired property under investigation. The 2018 amendment allows the ACC to initiate a preliminary investigation of the reported information received, while previously ACC could only take action on formal complaints. This amendment is seen as an effective measure in the fight against corruption, as it allows the ACC to use evidence of abnormal wealth income as a ground for investigation, it provides a convenient avenue for the ACC to investigate public officials who have acquired wealth or assets that are clearly beyond their capabilities. The law also cooperates with the "Anti-corruption Rules", "Criminal Code", "Criminal Procedure Law", "National Civil Service Law", "Anti-Money Laundering Law" and other legal systems to form Myanmar's Anti-corruption legislative system. The Anti-corruption Law, as the basic law in the field of corruption control in Myanmar, established a criminal legislation model focusing on post-mortem punishment, and played an important role in clarifying the legislative concept of criminal strikes and guiding the legislative direction of other auxiliary laws and regulations.

\section{Model of Preventive Legislation Focusing on Pre-Prevention}

The Anti-corruption prevention legislative model is to reduce the occurrence of corrupt psychology of relevant personnel through relevant regulations before the occurrence of corruption, so as to achieve the purpose of preventing corruption (Vian, 2020). This model emphasizes prevention first, and mainly builds legislation around the prevention mechanism. It achieves the purpose of preventing corruption by improving the Anti-corruption system, strengthening corruption supervision, and strengthening Anti-corruption propaganda, and generally does not involve criminal punishment.

Since Vietnam's Anti-corruption Law was first enacted in 2005, it has been revised three times in 2007, 2012 and 2018, and its content has been gradually refined and improved. As a typical model of Anti-corruption prevention legislation, its provisions on corruption prevention are as follows: First, by clarifying the specific connotations of concepts such as corruption, corrupt behavior, and conflict of interest, and limiting the scope of their adjustments, public officials can clarify what behaviors can be, What behaviors should not be done, so as to regulate their own behavior when performing their duties, not to touch the legal red line, and to maintain a clean style at all times. The second is to clearly stipulate the principles, content, methods, and responsibilities of information disclosure, and require the government to hold regular or temporary press conferences, press conferences, etc., to provide the media with its corruption governance measures and the handling of corrupt acts or cases. Situation and other information; the central and local governments at all levels are required to report and publish their work in preventing and punishing 
corruption every year. On the one hand, this regulation guarantees citizens' right to supervise, and on the other hand, it is conducive to creating a "Transparent and Sunny Government". The third is to clarify the code of conduct for public officials through the establishment of a conflict of interest mechanism and a position rotation mechanism, and stipulate that when a conflict of interest occurs that makes it impossible to continue to perform their duties, the performance of the personnel with conflicts of interest shall be reviewed, and the performance of their duties shall be suspended or temporarily suspended. Or transfer them to other positions temporarily. At the same time, it is stipulated that the jobs of cadres and civil servants who are not leaders and management positions shall be exchanged regularly, and the exchange shall be fair, just, and professionally matched. While preventing the breeding of corruption, this provision is also conducive to the protection of the legitimate rights and interests of public servants. Fourth, through the establishment of a property declaration system, the personal property of public officials, their spouses, and minor children's property and changes are supervised, and individuals who fail to declare their property truthfully and who fail to truthfully explain the source of the increased portion of their property will be dealt with seriously. At the same time, increase the property identification system and income inspection system to further supplement and improve the personal property declaration. Fifth, by stipulating the responsibility system of the first person in charge of various state agencies, non-state-owned enterprises, non-public entities and institutions, organizations and units, all parties can take various measures to prevent and detect corruption within the scope of their own duties. Fight all kinds of corruption and create a clean government atmosphere. Sixth, by strengthening international cooperation in asset seizure, account freezing, confiscation, and recovery of corrupt assets, we should eliminate the idea of those involved in corruption fleeing abroad to avoid punishment at home, and maintain their own integrity and integrity, in order to prevent corruption (Liu, 2020).

The prevention of corruption is a requirement of the United Nations Convention against Corruption. The Anti-corruption Law regards the prevention of corruption as the main aspect of Anti-corruption. This is a requirement for fulfilling the obligations of the Convention and an important measure in line with international Anti-corruption standards (Zhang \& Liu, 2013). Since the implementation of the reform and opening up in 1986, the Vietnamese government has gradually improved relevant supporting regulations, such as the introduction of legal documents such as the Officials and Civil Servants Law, the Complaint and Accusation Law, which not only broadened the development path of Anti-corruption rule of law, but also further It clarified the importance of preventing this corruption governance mechanism, and to a certain extent contained the undesirable situation of the rapid spread of corruption in Vietnam. 


\section{A Comprehensive Legislative Model That Combines Criminal Punishment with Advance Prevention}

The comprehensive Anti-corruption legislative model combines the characteristics of prevention at the source and the suppression of the criminal model. It is a balanced legislative model that integrates pre-prevention and criminal punishment. In the specific legislative practice, some countries may place more emphasis on the prevention part in terms of provision, while the punishment part is used as a supplement to the existing criminal law and criminal procedure law.

\subsection{Philippines Anti-Corruption Act}

In the 1950s, bureaucratic corruption has become a major public issue since the independence of the Republic of the Philippines. The Anti-corruption Act No. 3019 (Republic Act No. 3019) promulgated in August 1960 was the first Anti-corruption basic law in the history of the Philippines (Quah, 2018). It adopts a comprehensive legislative model design that integrates pre-prevention, corruption discovery, and post-mortem punishment. It provides comprehensive regulations for civil servants' corruption, and its structure is exquisite. In just 16 articles, one All the essentials of comprehensive laws are included.

The "Anti-corruption Acts Act" arranges the corruption prevention clauses in Articles 3 to 6 after the General Provisions. The most important content is that in Article 3, it treats eleven public officials as acts of corruption as stipulated in the Constitution. For example, soliciting or accepting benefits in transactions between the government and other parties; deliberately delaying administration in order to obtain monetary or material benefits or benefits, etc., almost cover all aspects of possible corruption of public officials. According to the law, most corruption cases will be prosecuted. Articles 4 to 6 respectively prohibit the relatives and friends of state officials from turning this relationship into a profit for private collection of property and benefits; prohibit the president, vice president, the speaker of the Senate or the spouse of the speaker of the House of Representatives, or blood relatives or in-laws within three generations from directly or indirectly interfering with anything. Government-related business; members of Congress and state officials who have legislative powers are prohibited from preferring to legislate because of receiving benefits. These three regulations block the way for political families to exchange economic benefits through power while in office, but there are no regulations on the exchange of political benefits and the acquisition of economic benefits after retirement. This is where the corruption of Philippine officials is most rampant. In addition to prohibitions, the Anti-corruption Act will also include provisions that facilitate the detection of corruption. For example, Article 7 requires public officials to submit a detailed statement of assets and liabilities for review every year. In addition, it also stipulates Rules for property declaration, unexplainable property confiscation, etc. Regarding the ex post punishment clauses, Article 8 of the decree is similar to the crime of unidentified sources of huge amounts of property in China. It 
stipulates that if the amount of property and money of a state official during his tenure exceeds the proportion of his salary and other legal income, it constitutes a reason for removal or dismissal. Article 9 states that all state officials or private individuals who commit the illegal acts or omissions listed in Articles 3, 4, 5, and 6 shall be sentenced to imprisonment alone or concurrently, permanent disqualification for public office, or confiscation of unexplainable Property, state officials who violate Article 7 will face dismissal or criminal prosecution.

In general, the Anti-corruption and Corruption Act also focuses on corruption prevention and criminal punishment, and strives to provide for the prolongation of corruption through enumeration methods, so as to prevent public officials from obtaining improper benefits through the convenience of their positions. This is considered to be in the legal history of the Philippines. Milestone legislation, since its introduction in the 1960s, is still a solid basis for combating corruption.

\subsection{Lao Anti-Corruption Law}

Since the reform and opening up in 1986, the Laos economy has developed rapidly, but due to the lack of supporting Anti-corruption laws and regulations at that time, the corruption problem in Laos has become increasingly serious. In 1992, the Lao People's Revolutionary Party promulgated the "Anti-corruption Regulations" at the Fifth Plenary Session of the Fifth Central Committee, and established the Anti-corruption Committee the following year to rectify corruption in Laos through legal means. The Anti-corruption Law promulgated in 2005 marked that Laos has raised its Anti-corruption work to the height of national laws, and made some partial revisions and improvements in 2012, and finally formed the current effective Anti-corruption basic law of Laos. The Lao Anti-corruption Law focuses on the governance of the whole process of corruption, and has made explicit provisions in the aspects of prevention, investigation and punishment.

In terms of prevention, the Anti-corruption Law first emphasizes the principle of corruption prevention: it requires that we pay attention to corruption, investigate and handle corruption issues in a timely, strict, fair and accurate manner, and ensure that it is not interfered, hindered or threatened by any individual or group, and protect citizens, Social organizations and mass media can participate in preventing and combating corruption in accordance with regulations. In accordance with the principle of preventing corruption, the "Anti-corruption Law" also clarified measures to prevent corruption, such as emphasizing the prohibition of power rent-seeking and establishing a property declaration system, which laid the foundation for subsequent detection and containment of corruption. In terms of supervision, the "Anti-corruption Law" clarifies the obligations of the investigator and the person being inspected, and provides detailed regulations on the supervision of investigation procedures, investigation results, and implementation of corruption recommendations. Effective supervision of public offi- 
cials can prevent non-corrupted personnel from being corrupted, and the timely detection of corrupted personnel, and it is also conducive to the application of measures to punish corruption crimes. The Anti-corruption Law also encourages all social entities to report and expose corruption, and provide security protection, rewards, and other appropriate policy protections for individuals or organizations that provide information about corruption. The "Anti-corruption Law" actually establishes a cooperative mechanism for coordinating various forces in society to promote corruption investigations more efficiently and smoothly. In terms of punishment, the "Anti-corruption Law" provides for disciplinary sanctions and criminal penalties. For minor corruption behaviors, corrupt personnel are usually given education and disciplinary sanctions; for corrupt behaviors that meet criminal standards, corrupt personnel will be held criminally responsible. In addition, corrupt personnel must compensate for the economic losses caused by corrupt behavior. For example, any government staff member who deceives or falsifies any technical standards in construction, survey, design or calculation will be punished by imprisonment of one to five years and a fine of $1 \%$ of the damage value.

Generally speaking, the Lao Anti-corruption Law is relatively comprehensive. It is engaged in comprehensive legislation in three aspects: pre-prevention, mid-event supervision, and post-mortem punishment. The Law, the Asset Declaration Act and other laws cooperate with each other to jointly prevent and combat corruption.

\section{The Legislative Model Evaluation and Possible Options for China}

\subsection{Comment on the Legislative Model}

The basic law of Anti-corruption, which adopts the criminal legislation model, focuses on post-mortem punishment and pays more attention to the crackdown and suppression of corruption and bribery. Its advantage lies in the ability to formulate appropriate criminal punishment content according to the characteristics of a country's corruption crimes, and at the same time, it can play the role of punishment, deterrence and education. However, in this mode, the corresponding legislative work can only be made after the emergence of corruption. After the tedious and lengthy legislative procedures, the actual situation might have changed long ago. Therefore, this kind of passive legislation will inevitably have a lag.

The prevention legislation model has unique advantages in curbing the growth of corruption. For example, a series of measures such as the regulation of property declaration system to supervise the personal property of public officials, the identification of huge amounts of property of unknown origin, and the clarification of the corruption prevention responsibilities of relevant subjects, will stifle corruption in the bud. However, it favors the prevention of unborn corruption and weakens the punishment of existing corruption, resulting in low 
cost of corruption, and it is also easy to induce corruption, which is not conducive to subsequent corruption control work.

The comprehensive legislative model emphasizes the organic combination of front-end prevention and back-end punishment of corruption in the process of norm-setting, and focuses on the comprehensive management of corruption-not only by restricting the exercise of public power to prevent abuse of power, but also paying attention to rent-seeking in power. After the occurrence of the punishment of corrupt elements, relevant procedures and regulations will be formulated to promote the functional coordination and effective connection of corruption prevention and punishment. It can be said that the comprehensive legislative model realizes the organic unity of prevention and punishment, investigation and handling, and criminal punishment and administrative sanctions at the same time.

In different countries, the above three legislative models have played an active role in curbing corruption to varying degrees, but each has its own advantages and disadvantages. In fact, the choice of a country's Anti-corruption legislation model depends more on the actual needs of the country's Anti-corruption. For China, we must choose carefully based on China's national conditions and formulate a basic Anti-corruption law with Chinese characteristics.

\subsection{Possible Options for China}

An Anti-corruption basic law can show the country's Anti-corruption work concept and orientation, not only helps to improve the systemicity, integrity and coordination of Anti-corruption law formulation, reflects legislative force, but also saves legislative resources and costs (He \& Zhang, 2015). Although China's Anti-corruption legislation has changed from a simple criminal attack to a multi-point simultaneous system construction, unfortunately, the basic Anti-corruption law has not yet been promulgated. The concepts, policies, directions, and specific systems of Anti-corruption are still scattered in various departmental laws, regulations, documents, and internal party regulations (Liu \& Ji, 2016). The "Supervision Law" promulgated in 2018 is the latest achievement of China's special Anti-corruption legislation (Zhang, 2020), but from the perspective of its legislative purpose and clause setting, the "Supervision Law" mainly regulates the power operation of supervisory agencies, and lacks the top-level design of the system. Realize the basic function positioning and objectives of the Basic Law of the Anti-corruption Law.

Through the evaluation and analysis of the three Anti-corruption legislative models, it is not difficult to find that, in the long run, China's Anti-corruption work requires an Anti-corruption basic law under the comprehensive legislative model. In addition to its own advantages of the comprehensive legislative model, it also fits perfectly with the current "Zero Tolerance" Anti-corruption legislative concept: China used to emphasize the special governance of corruption and overly relied on severe penalties to control corruption; but under the guidance of 
the "Zero Tolerance" concept, China has turned to actively control corruption from the source, combining prevention and punishment.

Under the comprehensive legislative model, China's basic Anti-corruption law can be named the "Anti-corruption Law of the People's Republic of China", and the top-level design of corruption governance should be considered from the two aspects of "Prevention" and "Punishment." In terms of corruption prevention, consider establishing a management system for public officials, which mainly involves public officials' codes of conduct, prevention of conflicts of interest, and property declarations. In terms of corruption punishment, given that the Supervision Law already has the function of an organic law, China's basic Anti-corruption law can no longer repeat the relevant provisions of the Anti-corruption agency, but should focus on the construction and improvement of relevant criminal entities and procedural norms. For example, including the whistleblower protection system and improving the witness protection system, so that more people can actively and confidently participate in corruption punishment work, and gather more Anti-corruption forces. In order to change the current situation where China's Anti-corruption legislation lacks a macro program, an Anti-corruption basic law that integrates prevention and punishment under a comprehensive legislative model may be the best choice.

\section{Funding}

This article is the phased achievement of the "Innovation Project of Guangxi Graduate Education" (YCSW2021062) funded by the Guangxi Graduate Education Innovation Program.

\section{Conflicts of Interest}

The authors declare no conflicts of interest regarding the publication of this paper.

\section{References}

Gong, T., \& Yang, S. L. (2019). Controlling Bureaucratic Corruption. In Oxford Research Encyclopedia of Politics. https://oxfordre.com/politics/view/10.1093/acrefore/9780190228637.001.0001/acrefore$\underline{9780190228637-e-1463}$

He, J. H. \& Zhang, X. M. (2015). Research on Anti-Corruption Legislation. Criminal Science, 6, 3-22.

Hope Sr., K. R. (2017). Fighting Corruption in Developing Countries: Some Aspects of Policy from Lessons from the Field. Journal of Public Affairs, 17, Article ID: e1683. https://doi.org/10.1002/pa.1683

Liu, X. H. (2020). Vietnam Anti-Corruption Law. Southeast Asian Studies, 3, 24-51.

Liu, Y. H. (2017). Research on Anti-Corruption Legislation in China (p. 128). China Legal Publishing House.

Liu, Y. H., \& Ji, Y. (2016). On Construction of Anti-Corruption Basic Law. Administrative Law Review, 2, 18-26. 
Mansoor Marican, Y. (1979). Combating Corruption: The Malaysian Experience. Asian Survey, 19, 597-610. https://doi.org/10.2307/2643897

Michael, T. (2019). Humanity in the Enforcement of Anti-Corruption Laws. Jurnal Hukum Bisnis Bonum Commune, 2, 211-215. https://doi.org/10.30996/jhbbc.v2i2.2597

Nawab Zadah Khan, M. S. K., Mat Ghani, N., \& Mohamad, N. (2006). Prevention of Corruption Practices in Malaysia: "Suitability of Deterrent Sentence". https://ir.uitm.edu.my/id/eprint/31970/

Peng, X. L. (2021). On the Legislative Improvement of the Criminal Law of Corruption Crime in China. Law Science Magazine, 3, 68-77.

Quah, J. S. (2018). Combating Corruption in Asian Countries: Learning from Success \& Failure. Daedalus, 147, 202-215. https://doi.org/10.1162/daed a 00511

Vian, T. (2020). Anti-Corruption, Transparency and Accountability in Health: Concepts, Frameworks, and Approaches. Global Health Action, 13, Article ID: 1694744. https://doi.org/10.1080/16549716.2019.1694744

Wei, C. D. (2016). Corruption Governance Model and China's Anti-Corruption Legislative Choice. Social Science Front, 6, 197-205.

Zhang, Q. Y., \& Liu, M. (2013). Discussion on Punishment and Prevention of Corruption Legislation. Gansu Social Sciences, 6, 144-146.

Zhang, Y. X. (2020). On Several Problems of the Implementation of the Supervision Law of China and Its Improvement. Law Science Magazine, 41, 41-49. 